Araştırma Makalesi

\title{
Reklamlarda Korku Çekiciliği Unsurunun Kullanılmasi: Televizyon Reklamlarına Yönelik Bir Analiz
}

\author{
Mehmet Burç (Doktora Öğrencisi)
}

iD Erciyes Üniversitesi Sosyal Bilimler Enstitüsü

burcmehmet@hotmail.com

Derya Başakcı (Arş. Gör.)

Gaziantep Üniversitesi Iletişim Fakültesi

deryakirac10@gmail.com

Mustafa Koçer (Prof. Dr.)

(iD) Erciyes Üniversitesi Illetişim Fakültesi

mkacur@erciyes.edu.tr

Başvuru Tarihi: 19.02.2021

Yayına Kabul Tarihi: 28.04.2021

Yayınlanma Tarihi: 30.07.2021

https://doi.org/10.17680/erciyesiletisim.882805

Öz

Rekabetin artması ürün çeşitliliğini çoğaltmakta buna bağlı olarak reklamların sayısı artmaktadır. Ürünlerinin satın alınmasını amaç edinen markalar mesajlarda farklılaşma yoluna gitmiş, korku çekiciliğini kullanmaya başlamıștır. Korku çekiciliği, hedef kitleyi korku unsurları barındıran mesajları kullanarak ikna etme çabasıdır. Buradan yola çıkarak televizyon reklamlarında korku unsurlarının nasıl kullanıldığını ortaya koymayı amaçlayan bu çalışmada, 2018-2019 yılları arasında yayınlanmış ve içinde korku unsuru barındıran televizyon reklamları amaçlı örneklem yöntemiyle seçilmiştir. Korku çekiciliği modelleri ile ilişkilendirilen reklamlar göstergebilim tekniği ile analiz edilerek incelenmiștir. Araştırmanın sonucunda korku çekiciliği içeren mesajların insanlara, reklamlarda anlatılan tavsiyelere uymadıklarında başlarına gelecek olumsuz sonuçlara işaret edecek şekilde lanse edildiği tespit edilmiştir. Reklamların sonunda ise korkuyu gidermenin yolunun markaların kendi ürünleri ile mümkün olacağı sunulmuştur. Reklamlarda "fiziksel", "kişisel" ve "sosyal" tehdit unsurlarının yoğun olarak kullanıldığı görülmüştür. Korku çekiciliği reklamlarının ağırlıklı olarak sigorta ve kasko şirketlerince uygulandığı belirlenmiştir.

Anahtar Kelimeler: Korku, Korku Çekiciliği, Korku Çekiciliği Modelleri, Reklam, Göstergebilim. 


\title{
The Use of Fear Appeal in Advertisements: An Analysis of Television Advertisements
}

\author{
Mehmet Burç (Ph.D. Student) \\ iD Erciyes University Institute of Social Sciences \\ burcmehmet@hotmail.com \\ Derya Başakcı (Res. Asst.) \\ iD Gaziantep University Faculty of Communication \\ deryakirac10@gmail.com \\ Mustafa Koçer (Prof. Dr.) \\ D Erciyes University Faculty of Communication \\ mkacur@erciyes.edu.tr \\ Date Received: 19.02.2021 \\ Date Accepted: 28.04.2021 \\ Date Published: 30.07 .2021 \\ https://doi.org/10.17680/erciyesiletisim.882805
}

\begin{abstract}
Increasing competition increases product range and the number of advertisements increases accordingly. Brands aiming to buy their products have gone down the path of differentiation in messages and they started using fear appeal. Fear appeals is an effort to persuade the target audience using messages this contain factor of fear. And on that basis, this research aims to reveal how factor of fear are used in television advertisement. This research the use of fear appeal in televisions advertisement in 2018 and 2019, were used as an oriented. The advertisements associated with the fear appeal models were analyzed and analyzed using the semiotic technique. As a conclusion of the research the advertisements with fear appeal shows people what negatives can be if they don't obey the suggestions in the advertisements. At the end of the advertisements, it is presented that the way to eliminate the fear will be possible with the brands " own products. "Physical" "personal" and "social" threat factors were used intensely in advertisements. Fear appeal advertisements determined to applied the predominantly insurance companies.
\end{abstract}

Keywords: Fear, Fear Appeals, Fear Appeals Models, Advertisement, Semiotics. 


\section{Giriş}

Küreselleşme sürecinin getirdiği yoğun rekabet ortamında markalar ürünlerini satma arzusu ile reklamlara büyük önem vermeye bașlamış ve ürettikleri malları hedef kitleye tanıtmak amacıyla yoğun olarak reklam faaliyetlerine girişmişlerdir.

Reklam, işletmelerin ürünlerini satmak için, bir mala ya da hizmete ilişkin bir iletiyi medyadan yer ve zaman satın alarak sözlü ya da görüntülü olarak pazar birimlerine sunmak için ürün ve hizmetlerinin tanıtımını kapsayan iletişim unsurudur (Classer, 1972, s. 30). Reklamlar gazete ve dergilerde basılı yayınlar olarak, radyo ve televizyonlarda, gelişen internet teknolojileriyle de dijital platformlarda yayınlanmaktadır.

Reklamlarla ulaşılmak istenenler genel anlamda şunlardır: (Kocabaş \& Elden, 2011, s. 23-24)

- Tüketici üzerinde farkındalık oluşturarak dikkat çekmek

- Tüketici ile iletișim kurmak ve onlara bilgi vermek

- Mal ve hizmetlerin tüketimini kısa ya da uzun dönmede arttırmak

- Mal ve hizmete karşı talep yaratmak

- Kâr elde etmek

- İşletmenin saygınlığını arttırmak

- Alışkanlıkları değiştirmek

- Piyasaya ve pazara egemen olmak vb. şeylerdir.

Reklamlar hangi türde ve hangi mecrada yapılırsa yapılsın en temel amacı ürünlerin satışını yapmaktır. Bunun içinde ilk önceliği insanları ikna etmektir. İkna en genel anlamda, "Bilinçli ve planlı bir şekilde birey ya da bireyleri etkileme çabasıdır" (Madran, 2019 , s. 23). İnsanlar üzerinde etki olușturarak onların ürünleri satın alması teşvik edilmeye çalışılır. Tüketicileri ikna etmek amacıyla yapılan reklam faaliyetlerinin başında şüphesiz televizyon reklamları gelmektedir. Televizyon reklamları üreticiler tarafında çok sık olarak kullanılan reklam platformudur. Markalar televizyon reklamlarında hedef kitleyi ikna edebilmek için çeşitli çekicilik unsurları kullanılırlar.

Reklamda çekicilik, firmaların ürettikleri ürün ya da mallara yönelik tüketicilerin duygularını etkilemek için reklamlarda kullandıkları yaklaşımlar ve savlardır. Kısaca reklamın yönlendirdiği güdüde denilebilmektedir (Roland \& Russell, 1996, s. 512).

Reklamda çekicilik unsurları rasyonel ve duygusal olarak iki türe ayrılmaktadır (Tarakcı, 2019, s. 107). Rasyonel çekicilik türünde ürünün fiyatı, kalitesi, ne fayda sağladığı, performansı gibi özellikler üzerinde durulur (Davies, 1993, s. 51). Duygusal çekicilik ise kendi arasında üçe ayrılmaktadır. Esprili ve komik unsurların yer aldığı mizah çekiciliği, seksi ögelere yer verilerek kişisel haz duygularını ön plana çıkarıldığı cinsel çekicilik ve korku ve tehdit ögelerinin kullanıldığı korku çekiciliği reklamlarda kullanılan duygusal çekicilik metotlarıdır (Salmanova, Ergin, \& Yılmaz, 2018, s. 214-215).

Reklamlarda çekicilik unsurları arasında en yaygın kullanılan tekniklerin başında korku çekiciliği gelmektedir. Bu reklamlarla marklar insanlar üzerinde korku ve tehdit unsurları oluşturarak adeta ürünü satın almaya zorlanmaktadırlar. Reklamlarda hedef kitleler birçok korku dolu mesaja, görsele, içeriğe maruz kalmaktadır. Tüm bunlardan hareketle çalışmada reklamlarda kullanılan korku çekiciliği unsurları işlenecektir. İlk olarak literatür bölümünde korku çekiciliği kavramı detaylı olarak açıklanarak ne anlam ifade ettiği belirtilecektir. Daha sonra korku çekiciliğini etkileyen önemli unsurların neler 
olduğu tespit edilecek ayrıca korku çekiciliği ile ilgili bulunan modellere değinilerek korku çekiciliği unsurunun hangi teorilerden oluştuğu açıklanacaktır. Tüm bunlar açıklanıp korku çekiciliği kavramı pekiştirildikten sonra bu unsurların reklamlarda kullanımı ele alınacaktır. Yöntem bölümünde ise televizyon reklamları incelenerek bu reklamlarda kullanılan içerisinde korku çekiciliği ögeleri barındıran örnekler seçilecek ve bu incelemeler neticesinde elde edilen bulgular analiz edilecektir.

\section{Korku Çekiciliği Kavramı}

Korku genelde normal, doğal, evrensel olarak deneyimlenmiş bir duygudur (Kekes, 2013, s. 555). Çünkü korku, hayatın doğal bir parçası olarak herhangi bir tehdit unsuru ile karşılaşıldığında ortaya çıkmaktadır (Debiec \& Joseph, 2004, s. 807). Bu nedenle bu duygu insanı tarih boyunca tehlikelerden korumuş ve insan ırkının devam ettirilebilmesinde temel unsurlardan biri olmuştur (Elden \& Bakır, 2010, s. 265). Korku TDK tarafından; "Gerçek veya beklenen bir tehlike ile yoğun bir acı karşısında uyanan ve coşku, beniz sararması, ağız kuruması ve kalp atışı hızlanması vb. belirtileri olan veya daha karmaşık fizyolojik değişmelerle kendini gösteren duygu" olarak tanımlarken (Tdk, 2020), Young ise korkuyu "içinde bulunulan ortamın algılanması ile ortaya çıkan, iç organları harekete geçiren, bedende, davranışta ve bilinçte kendini belirten duygusal bir süreç olarak tanımlamıștır (Young 1998'den aktaran; Cüceloğlu, 2008, s. 264).Tüm bunlara ek olarak Fisher'a göre ise korkunun doğasında deneyim, ideolojiler, mitler, inançlar, değerler ve imgeler bulunmaktadır. Ona göre korku insan yapımı olup yıkıcı ve zehirleyicidir, "doğal" veya doğamızın bir parçası değil, kültürel olarak inşa edilmiştir (Fisher, 2012, s. 14-19).

Korku kültürü ise, bireyler bir olay, bir olgu karşısında birleştiği zaman toplum olma yoluna girmiş bulunmaktadır. Aynı duyguları paylaşan, aynı durumları kabul eden insanlar var olabilme yetkinliğine erişmiş olurlar (Mannoni, 1992, s. 90).

Korku en temel duygulardan birisidir. $\mathrm{Bu}$ duygu aracılı̆̆ belki de ilk insanlar toplumsallaşma yoluna girmiş beraber yaşama fikri edinmişlerdir. Ancak korku duygusu günümüzde toplumsallaşmanın da bir sonucu olarak her alanda kendini gösterir bir hale gelmiştir. Furedi, öğrenim gören öğrencilerin okulda zarar görmemesi için takılan güvenlik kameralarından hastanede gelişen virüslere, tükettiğimiz gıdalardan giydiğimiz giysiye, içtiğimizden sudan soluduğumuz oksijene kadar her alanda hayatımıza sirayet eden korkulardan bahseder. Bu gibi durumlardan dolayı artık korkan bireylerde güvende olma duygusu baskın olmaya bașlamıștır. Güvenliği sağlama nedeniyle oluşturulan pazar ise gittikçe gelişen bir sektör haline gelmiştir. (Furedi, 2017, s. 27).

Korkunun kültürel doğrultuda kendine yer bulmasının nedeni bir uyum aracı olarak işlev görmesinden kaynaklanmaktadır (Eren, 2005, s. 2). Bu nedenle politika, sanat, din, ahlak, bilim vb. alanlarda korkuya dair izler görülmektedir (Elden \& Bakır, 2010, s. 272). Korku duygusu farklı alanlarda karşımıza çıksa da altındaki sebep sen-ben anlayışına dayanmaktadır. Sen anlayışında bireyler sorumluluk almamakta ve kontrolü otoriteye devretmektedir. Ben anlayışında ise durum tam tersi işlemektedir. Ben anlayıșına sahip bireyler her türlü durumu kontrolü altına almak istemektedir (Eren, 2005, s. 3). Bununla birlikte Güler değerler kültürüne dayalı, demokratik anlayıșa sahip, bireylerin kendilerini ifade etmekte zorlanmayacağı "Biz Bilinci" oluşturulması gerektiğinden bahsetmektedir (Güler, 2001, s. 194-195).

Korku, bireyleri harekete geçirmek amacı ile de kullanılmaktadır. Bu duyguya yönelik yapılan faaliyetlerle kuruluşlar karlarını arttırmakta ve pazarlama aracı olarak 
kullanmaktadır (Öztürk \& Sevinç, 2017, s. 892). Çünkü korkunun aynı zamanda tahrik ederek ikna etmeyi etkilediğine inanılmaktadır (Brooker, 1981, s. 29). "Korku ve ikna kavramlarının bir arada kullanımı, zaman içerisinde korku çekiciliği adında yeni bir kavramın ön plana çıkmasına neden olmuştur (Çakl, 2018, s. 87)”.

$\mathrm{Bu}$ bağlamda Witte, korku çekiciliği kavramını mesajın önerdiklerini yapmazlarsa başlarına gelecek korkunç şeyleri tanımlayarak insanları korkutmak için tasarlanmış ikna edici mesajlar olarak tanımlamaktadır. Bu tanımdan yola çıkarak iletilen mesajlar bireylerde korku uyandırmalı ve insanları konu hakkında düşünmeye sevk ederek önlem almak için harekete geçirmeye yönlendirmelidir diyebiliriz (Witte, 1992, s. 329)

Başka bir ifade ile korku çekiciliği, korku ögeleri kullanarak tüketicilere önerilen ya da tavsiye edilen herhangi bir durum ya da olaya karşı önlem almaları gerektiğini belirten, almamaları durumunda ise başlarına gelebilecek olumsuz olaylara dikkat çekip tehdit yoluyla insanları ikna etmeyi amaçlayan reklam yöntemidir (Mazıcı \& Çakı, 2018, s. 292).

Korku çekiciliği, ağırlıklı olarak duygusal ögelere seslenmektedir. Ancak kullanım yerlerine göre rasyonel yönlerde sunan tutum temelli bir ikna tekniği de olmaktadır. $\mathrm{Bu}$ teknikle insanlar bir şeye ikna edilirken korku uyandırılmaya çalışılmakta ve belli bir davranışı yapmanın sonucunda ortaya çıkabilecek zararlar sıralanmaktadır (Kalender, 2005, s. 126).

Bir bireyin bir tehdidi nasıl algılayacağını ve buna nasıl tepki vereceğini etkileyebilecek bir dizi faktör bulunmaktadır. Bunlar; kişinin tehdide cevap vereceği eșiği, demografik özelliklerini ve davranışın sosyal sonuçlarını içermektedir. Bu faktörler ise dinamiktir. Tehdide yönelik verilen cevaplar ise zamanla değişme eğilimindedir veya algılanan tehdide verilen yanıt, yaşam tarzı değişiklikleri nedeniyle azalabilir veya artabilir (Lennon \& Rentfro, 2010, s. 98).

Ruiter vd. göre tehdit içerikli mesajların algılanması ile tetiklenen ve hoş olmayan bir durum olarak tanımlanan korku uyarısının azaltılması ya da ortadan kaldırılması için bu durumun bilişsel, duyusal ve davranışsal tepkiler içerdiği varsayılmaktadır. Teorik olarak korku çekiciliği iki türde bilgi sağlamaktadır. İlk olarak duyarlı olunan bir konu ve bu konu hakkında duyarlılığa yönelik mesaj oluşturulur ve bu mesaj şiddetli hale getirilerek korku pekiştirilir. Şiddet ve kişisel duyarlılık korkuyu uyandırmak için gerekli koşullardan olması yanı sıra mesajlarla alıcıyı harekete geçirmek için korku çekiciliğine etki eden unsurlar bulunmaktadır (Ruiter, Kessels, Peters, \& Kok, 2014, s. 65).

\section{Korku Çekiciliğini Etkileyen Önemli Unsurlar}

Reklamlarda sadece ürün özelliklerinin tanıtımı bazen ișe yaramamaktır. Benzer ürün ve reklamlardan çok fazla olduğu için bu durum tüketicinin dikkatini çekmeyebilir. Dolayısıyla üzerlerinde bir ikna unsuru oluşmaz. Bu nedenle markalar ürünlerini tanıtırken onları güdüleyecek tüketici üzerinde satın alma davranışı uyandıracak unsurlar işlerler.

Reklamlarda ikna yöntemi olarak kullanılan korku çekiciliği kapsamında ön plana çıkarılan, ikna olmaya etki eden önemli unsurlar işlenir. Witte korku çekiciliğine etki eden unsurları korku, tehdit ve yeterlilik olarak üç kategoriye ayırmıştır (Witte, 1992, s. 330).

- Korku: Mevcutta var olan tehlikeli bir durumun ya da tehlike yaratacak bir olasılığın ortaya konduğu negatif içerikli duygulardır (Witte, 1992, s. 331).

- Tehdit: Witte tehdidi kişinin bilincinde olup olmaması fark etmeksizin olumsuz bir durum oluşturacak tehlikeler olarak yorumlamıştır. Tehdidin varlığının algılanması 
tehdidin ciddiyetine ve tüketicilerin tehditten etkilenme hassasiyetine bağlıdır. Tehdidin ciddiyeti, kişilerin tehdidin oluşturacağı ciddiyete ilişkin inançlarını ifade eder. Tehditten etkilenme hassasiyeti ise kişinin tehditlere karşı savunmasızlığı, duyarlılığı ve deneyimlerini ifade etmektedir (Witte, 1992, s. 331-332).

- Yeterlilik: Çevresel ya da mesajla ilgili bir durumdur. Hedef kitlenin belirlenen tepkiyi idrak edebilme yeteneğine odaklanır. Bu duruma öz yeterlilik denmektedir (Rogers, 1975, s. 102-103).

Korku çekiciliğini oluşturan bu unsurların reklamlarda kullanımı neticesinde tüketicileri ikna etmedeki katkısı çeşitli modellerle ortaya konulmuştur.

\section{Korku Çekiciliği Modelleri}

Witte ve Allen 1953 yılından günümüze kadar korku çekiciliğini ele almış korku çekiciliğinin çeşitli alanlarda kullanımına yönelik birçok model ortaya konulduğundan bahsetmiştir (Witte \& Allen, 2000, s. 591-592). Ancak çalışmada sadece reklamlara yönelik kullanılan modeller ele alınacaktır. Elden ve Bakır'a göre bu modeller itki modeli, paralel tepki modeli, Thayer tahrik modeli, korunma motivasyonu kuramı ve son olarak genişletilmiş paralel işleme modelidir (Elden \& Bakır, 2010, s. 287).

\section{1. İtki Modeli}

Korkunun, hoş olmayan bir durumdan bireyleri kurtarmak için motive etmeye yönelik kullanıldığı bir güç olarak kavramsallaştırıldığı bir modeldir. Bu modele göre mesaj yeterince korku uyandırıyorsa ve alıcıda duygusal gerginlik oluşturuyorsa mesajın ikna etme gücü de artacaktır. İki varsayım üzerine kurulu olan itki modeline göre ilk olarak korku yeterince yoğun olduğunda harekete geçme eğilimi de artmaktayken; ikinci varsayıma göre ise, korkunun azaltılması durumunda bilişsel ya da davranışsal tepkinin olumsuz durumu da azalacaktır (Williams, 2012, s. 68). Janis daha sonra ileri sürmüş olduğu itki modelini gözden geçirerek "Ters U Modelini” ortaya koymuştur. $\mathrm{Bu}$ modele göre motivasyon ve korku arasındaki ilişkiyi ters çevrilmiş bu şeklinde tanımlamıştır. Janis'e göre korku uyarısının olması korku durumundan kurtulmak için gerekli motivasyon kaynağıdır. Bununla beraber korkuya neden olan durumun negatif etkisini ortadan kaldırmak amacıyla harekete geçmeye yönelttiğini de savunmuştur (Johnston \& Warkentin, 2010, s. 551). Bu modele göre orta düzeyde iletilen korku mesajları alıcı üzerinde daha çok etkiye neden olmaktadır. Tehlike karşısında bilinçli olan birey orta düzeyde korku unsuru içeren mesajlardan kaçmamakta ve böylece istenilen davranış değişikliği yaratılmaktadır. Ancak yüksek korku unsuru barındıran mesajlar karşısında alıcı korku unsurundan sakınmakta ve istenilen davranışların kabulü gerçekleşmemektedir (O’Keefe, 1990, s. 210).

\subsection{Paralel Tepki Modeli}

1970 yılında Leventhal tarafından önerilen modelde korku çekiciliğinde paralel tepki süreçlerini tehlike kontrol süreçleri ve korku kontrol süreçleri olmak üzere iki ayrı süreç ama bununla beraber potansiyel olarak birbirine bağlı süreçler olarak ifade etmiştir (Witte \& Allen, 2000, s. 593). Leventhal, korku çekiciliği içeren mesajlar alıcılar tarafından tehlikeli olarak yorumlandığında tehlike unsurlarını en aza indirgeme çabalarına gireceklerini belirtmiştir (Leventhal, 1971, s. 1210). Çünkü bu modele göre bu iki unsur paralel olarak birbirini etkilemektedir. 


\subsection{Thayer Tahrik Modeli}

Korku çekiciliği bireyin davranışının değişmesi için bir tür uyarılmanın gerekli olduğunu varsayar. Thayer psikofizyolojik süreçle birlikte reklam uyaranlarını uyandırmaya yönelik duygusal tepkileri incelemiştir. Uyarılmayı tetikleyen boyutları gerginlik, enerji, sakinlik ve yorgunluk olarak ele almıştır. Thayer'e göre, aşırı olmayan bir uyaran bireyde gerginliğe neden olarak enerji üretir ancak gerginlik aşırı ise enerji azalacaktır. Enerji pozitif duygular üretirken yüksek gerilim seviyeleri olumsuz duygular üretir. Ek olarak Thayer insanların davranışlarının çoğunu hoş olmayan durumlardan uzak durmaya çalışarak huzurlu durumlara doğru ayarladığını belirtmiştir. Yani bu duruma göre; aşırı olmayan bir korku çekiciliği unsuru taşıyan reklama karşı olumlu bir duygu uyarana aracılık edecekken yüksek gerilim üreten mesajlar gerilime neden olacaktır (Williams, 2012, s. 70).

\subsection{Koruma Motivasyonu Modeli}

Rogers, korku çekiciliğinin daha geniş bir birleşimine bakıldığında bireyin tepkisinin daha iyi tahmin edilebileceğini ileri sürmüştür. Bu modele göre korku çekiciliğine ilişkin unsur içeren mesajlara bireyler çeşitli öğeleri göz önünde bulundurarak tepki gösterirler (Elden \& Bakır, 2010, s. 294). Bu ögelerden oluşan mesaj bileşenini Mongeau şu şekilde özetlemektedir; algılanan tehdidin zarar verme oranı, önleyici bir önlem alınmadığı takdirde tehdidin gerçekleşme oranı, önerilen başa çıkma tavsiyesinin etkililiği ve son olarak alıcının öz yeterlik yeteneğidir (Mongeau, 1998, s. 56). Bu kurama göre, bu unsurların tümü yüksek olduğunda koruma motivasyonu oluştururlar ancak düşük olduğu takdirde birey önerilen çözümü kabul etmeyecektir.

\subsection{Genişletilmiş Paralel İşleme Modeli}

Kim Witte, Leventhal ve Rogers tarafından ortaya konan korku çekiciliği modellerini temel alarak bu modeli geliştirmiştir (Sheer \& Chen, 2008, s. 938). Bu modele göre ilk olarak bireyler mesajın taşıdığı korku unsurunu değerlendirir ve ne kadar çok ciddi bir tehditle karşı karşıya kaldıklarına inanırlarsa ikinci değerlendirmeye o zaman başlamaktadırlar. Tehdit ilgisiz ya da önemsiz olarak algılandığında ise motivasyon yok olur ve korku içeren mesajı görmezden gelirler. Buna karşılık bir tehdit ciddiyse ve bireyin kendisi ile ilgili olduğunu düşündüğü bir durum ise bireyler korkar ve korkuyu azaltacak bir eylemde bulunurlar. Bireyler tehdide karşı etkili bir yanıt verebildiklerine inandıklarında tehlikeyi kontrol etmeye, bilinçli olarak tehdidi ortadan kaldırmak veya azaltmak için düşünmeye güdülenirler (Witte \& Allen, 2000, s. 594).

Yukarıda belirtilen tüm unsurlar dikkate alınarak geliştirilen bu modellere bağlı olarak korku unsuru reklamlarda işlenmektedir.

\section{Korku Çekiciliğinin Reklamlarda Kullanımı}

Korku bireylerde endișe ve gerilim oluşturur. Kişiler korkuya maruz kalınca meydana gelen endișe ve gerilimden kurtulmak isterler. $\mathrm{Bu}$ nedenle markalar reklamlarda tüketicinin ilgisini çekmek için korku çekiciliğini kullanırlar. Korku çekiciliği unsurları reklamlarda ürün ve hizmet pazarlamada, toplumsal olaylarda farkındalık olușturmada ve siyasi bir fikrin benimsetilmesinde kullanılır (La Tour \& Zahra, 1988, s. 5-7).

İnsanları ikna etme noktası üzerinde reklamlar tarafından kullanılan negatif ögeler arasında en sık başvurulanı korkudur (Smith \& Mackie, 2007, s. 257). Reklamlarda korku çekiciliği ögeleri iki türlü işlenmektedir. Birincisi herhangi ürün ya da alışkanlıktan vazgeçmemiz gerektiğini ve bunları yapmaya devam ettiğimiz takdirde başımıza gelecek 
felaketleri anlatan kamu spotlarıdır. Sigara ve alkol alışkanlığı, trafik kurallarının ihlali kamu spotu reklamlarında sık başvurulan yöntemleridir. $\mathrm{Bu}$ reklamlarda belirtilen davranışları sürdürmeye devam edilirse kişinin başına gelecek sonuçlar yansıtılarak bireyler üzerinde korku oluşturularak onları bu davranışlarından caydırmak amaçlanır. İkincisi ise markaların hedef kitlesi üzerinde satın alma davranışı oluşturmak için ürünlerinin reklamlarında kullandığı korku ögelerinden oluşmaktadır. Kişilere reklamlarda yer verilen ürün ve hizmetleri kullanmadığı sürece başlarına olumsuz olayların geleceği, dişlanacağı, zor durumda kalacağı düşüncesi korku yoluyla empoze ettirilmeye çalışılır. Ev ve arabaların koruma altına alınmadığında herhangi afet, hırsızlık ve kaza olaylarında yaşanılacak zor durumları kişilerde korku uyandıracak şekilde gösteren sigorta ve kasko reklamları, güvenliği ön plana koyan otomotiv reklamları, pis kokular ve istenmeyen görüntüleri toplum üzerinde yadırganma ve dişlanma korkusu yaratarak işleyen deodorant ve krem reklamları örnek verilebilir. Bu reklamlar bireyler üzerinde sağlamak istediği yaşam tarzı ve alışkanlıkları korku üzerinden kurduğu baskı ile sağlamaya çalışmaktadır. Bu baskıyı siyasal ve toplumsal alanda gerçekleştirdiği gibi ekonomik alanda da sürdürmektedir. Korku çekiciliği barındıran reklamların temelinde yatan düşünce bireyleri huzursuz ederek kendilerini yetersiz görmelerini sağlayarak hoşnutsuzluklar aşılamaktır. İnsanlara korku yoluyla ürünü tükettiği ölçüde mükemmelliğe ulaşacakları gösterilmektedir (Becan, 2019, s. 151-152).

Reklamlarda korku oluşturulmaya çalışılırken yararlanılan unsurların başında tehdit ögesi gelmektedir. Ama iki kavram aynı anlamı vermemektedir. Korku, tehditler sonucu oluşan bir tepki yansımasıdır. Tehdit ise kişilerin kaçındıkları durumların kullanımıyla, onlarda korku oluşmasını sağlayan araçtır. Reklamlarda tehditler kullanılarak insanlarda korku oluşturulmaktadır (Tour \& Rotfeld, 1997, s. 46).

Reklamlarda kullanılan tehditler fiziksel olarak, sosyal olarak ve kişisel olarak korkuları tetiklemektedir (Elden \& Bakır, 2010, s. 298).

- Fiziksel Tehditler: Bir ürünü satın almama herhangi davranışta bulunma ya da bulunmama, bir fikri destekleme ya da desteklememe durumunda oluşacak olumsuz sonuçlar neticesinde oluşmuş tehditlerden beslenen korkulardır. Fiziksel tehditleri oluşturan unsurlar arasında ölüm, hastalanma, sakat kalma gibi fiziksel olarak kişiyi tehlikeye atan ve istenmeyen durumlardır. Daha çok trafik kazası, doğal afet ve hastalıklara karşı bilinçlendirme reklamlarında kullanılır (Elden \& Bakır, 2010, s. 298).

- Sosyal Tehditler: Toplumda diğer insanlarla bir arada yaşayan bireyin, diğer bireylerle girdiği ilişkilere ve etkileşimlere bağlı olarak oluşturduğu korkuları ele alarak işlenen tehdit unsurlarıdır. İnsanlar diğer insanlar tarafından beğenilmek isterler ve toplumdan dışlanma korkusu yaşarlar. Reklamlarda bu husustan yola çıkarak toplum tarafından beğenilmeme, dışlanma unsurları işlerler. Kepek sorunu ele alan şampuan reklamları, buna örnek olarak verilebilir (Elden \& Bakır, 2010, s. 300).

- Kişisel Tehditler: Bireylerin kendilerini algılamalarına ve anlamlandırmalarına ilişkin tehditlerdir. Bu reklamlarda kişinin sahip olduğu ve ona memnuniyet veren bir özellik ya da durumun kaybı halinde olacak sonuçlar üzerinden korku yaratılır. Bu duruma cinsel güç içerikli reklamlar örnek verilebilir. Cinsel güç artırıcı ilaçlar ve sigara karşıtı reklamlarda cinsel gücün azaldığına yönelik vurgular yapılması kişisel tehditlere örnek verilebilir (Elden \& Bakır, 2010, s. 301-302).

Reklamlarda kullanılan korku çekiciliği ölçeklerine göre çeşitli boyutlarda ele alınmaktadır. Bunlar düşük düzey korku içeren reklamlar, orta düzey korku içeren 
reklamlar ve yüksek düzey korku içeren reklamlardır (Strong \& Dubas, 1993, s. 93-99). Belirtilen bu korku düzeyleri ile kişilerin ikna olması arasında paralellik söz konusudur. Reklamlarda kullanılan korku düzeyi arttıkça buna bağlı hedef kitlede satın alma davranışı da artmıştır (Terblanche \& Terblanche, 2010, s. 121). Ayrıca korku hangi düzeyde kullanılırsa kullanılsın reklamlarda korku çekiciliği unsurlarından yararlanılarak amaca ulaşmak için iletişim hedeflerinin başarılı şekilde planlanması ve verilen mesajlarda oluşturulacak stratejilerin etkin biçimde tasarlanması gerekmektedir (Ray \& Wilkie, 1970, s. 54). Hazırlanan iletişim hedefleri ve sunulan etkin mesaj stratejileri ile korku çekiciliğinin reklamlarda başarılı bir şekilde yansıtılması hedef kitlenin istenilen yöne ikna olması hususunda önemli ölçüde ve hızlı şekilde etki edecektir (Siu, 2010, s. 580).

$\mathrm{Bu}$ çalışma bağlamında televizyon reklamlarında markların ürün ve hizmetlerini satmak amacıyla yayınladıkları ve yayınlarının içinde korku çekiciliği ögeleri barındıran reklamlar incelenecektir.

\section{Yöntem}

\subsection{Araştırmanın Amacı ve Önemi}

Bu çalışma kurumların hedef kitlelerini ürünlerini satın alma noktasında ikna etmek için reklam faaliyetlerinde yer verdikleri korku ögelerini temel almaktadır. Çalışmanın amacı yoğun rekabet ortamında farkındalık sağlamak için yürütülen reklamlarda tüketicide razı olma davranışı sağlamak için kullanılan çekicilik yöntemlerinin başında gelen ve sıklıkla kullanılan korku çekiciliğinin nasıl kullandığını, ne yönlerden işlendiği ve hedef kitleye ne şekilde iletildiğini göstermeye çalışmaktır.

Reklamlardaki korku ögelerinin incelenerek satın alma davranışı üzerinde ne gibi mesajlar verdiğinin çözümlenecek olması, bu konuda bir bilinç oluşturulmaya çalışılması araştırmanın başlıca önemini oluşturmaktadır. Ayrıca çalışmanın literatüre yeni bir bakış açısı katacak olması, korku çekiciliği konusuna farklı örnekler ve bulgular sunacak olması ve bundan sonraki korku çekiciliğine ait çalışmalara da kaynak olması araştırmaya ayrıca önem katmaktadır.

\subsection{Araştırmanın Yöntemi}

Çalışmada televizyonlarda yer alan ve korku çekiciliği mesajı içeren reklamlar nitel araştırma metodu olan göstergebilimi analiz tekniğinden yararlanılarak açıklanacaktır. Seçilen reklamlar, İsviçreli Dil Bilimci Ferdinand de Saussure'ün gösteren ve gösterilen düzlemleri üzerinden incelenerek analiz edilmiştir.

\subsection{Evren ve Örneklem}

Dünyanın her yerinde insanların ihtiyaçlarını karşılamak için ürün ve hizmet üreten sayısız işletme vardır. Bunlar arasında benzer ürünleri üreten birçok rakip firmada bulunmaktadır. Böylelikle yaşadığımız evrende hizmet sağlayan milyonlarca kuruluş tüm insanların her türlü beklentisine, isteğine ve zevkine cevap veren bir yapıda faaliyet sürdürmektedir.

Bunların yanı sıra tüketici bilinç ve ihtiyaçlarının artması, sürekli gelişen küresel rekabet piyasasında işletmelerin farkındalık sağlayabilmesi ve rakiplerinin önüne geçerek kendilerinin tercih edilmesi ve ürettikleri ürünlerinin talep görerek satın alınması için kurumlar tarafından etkin reklam çalışmaları sürekli olarak yürütülmektedir. Ayrıca günümüzde teknolojinin gelişmesi ve kitle iletişim araçlarının günlük yaşamın vazgeçilmezleri haline gelmesi reklam çalışmalarını daha da yoğunlaştırmıştır. 
Araştırmamızda korku ögeleri içeren reklamların araştırılmasından dolayı içerisinde korku çekiciliği unsurları barındıran reklamlar çalışmamızın evrenini oluşturmaktadır. Çalışmada amaçlı örneklem tekniği uygulanmıştır. Reklamların birçok platformlarda yayınlanmasından ötürü tüm evrene ulaşmak mümkün olmayacağ maruz kaldığı, reklam faaliyetlerinin yoğun olarak işlendiği böylelikle etkin bir tanıtım ve ikna silahı olan ve aynı zamanda korku ögelerinin hem görsel hem işitsel olarak görülüp algılanmasına olanak sağlamamasından ötürü televizyon reklamları örneklem olarak alınmıștır.

\subsection{Sınırlılıklar}

Çalışmada korku çekiciliği içeren reklamların evren olarak tercih edilmesine karşın televizyon reklamların örneklem olarak alınması çalışmaya sınırlılık getirmiştir. Ayrıca ele alınan reklamlar ulusal televizyon kanalları ile sınırlandırılmıştır. İncelenen reklamlarda satın alma davranışı sağlamak için markların verdiği korku mesajlarını görmek açısından herhangi kamu spotu reklamları tercih edilmemiş sadece ürün ve hizmet satışı sağlayan reklamlar analiz edilmiştir.

Araştırma hem yakın dönemlerde yayınlanan güncel reklamlardaki korku ögelerini göstermesi açısından hem de literatürde bu bağlamda daha önce çalışılmış araştırmaların 2017 yılını da kapsayacak şekilde detaylı analizlerin yer alması bu dönemden sonra literatürde belli boşluğun oluşması ve onun tamamlanması amacıyla çalışma 2018 yılı ile 2019 yılları arası sınırlandırılmıștır.

Televizyonlarda yayınlanan korku çekiciliği reklamlarının sektör ve sayısı oldukça fazladır. $\mathrm{Bu}$ yüzden belirlenen zaman dilimi olan 2018 ve 2019 yılları içerisinde reklamların tamamına ulaşmanın zor olması nedeniyle örneklem, korku çekiciliğininim temelini oluşturan her bir modele uygun ikișer reklam örneği ile sınırlandırılmıştır. Bu örnekler amaçlı örneklem sistemine dayandırılarak seçilmiştir.

\subsection{Araştırma Soruları}

Araştırmada cevap getirilmesi istenilen sorular şunlardır:

- Televizyon reklamlarında hedef kitleyi ikna etmek amaçlı korku çekiciliği içeren mesajlar nasıl gösterilmiş ve hangi ifadeler ön plana çıkarılmıştır?

- Reklamlarda ağırlıklı olarak hangi tür tehdit unsurlarına yer verilmiștir?

- Reklamlarda korkuyu gidermek için çözüm önerileri nasıl sunulmuştur?

- İncelenen örneklere bağlı kalınarak korku çekiciliği mesajları içeren reklamlar daha çok hangi sektörlerde görülmektedir?

Araştırma soruları kapsamında elde edilen cevaplara araştırmanın sonuç kısmında değinilecektir. 


\section{Bulgular ve Yorumlar}

\subsection{Domestos "Maksimum Hijyen" Reklam Analizi}

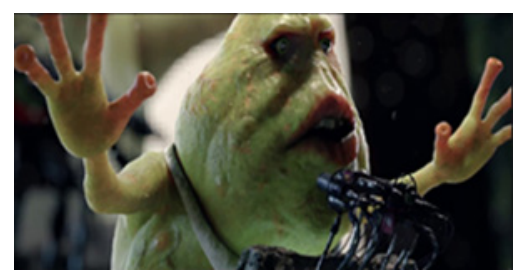

Şekil 1. Domestos "maksimum hijyen" reklam örneği

2018 yılında yayınlanan "Domestos Maksimum Hijyen” reklamı, tehdidin zarar verme olasılığının ve önerilen önlemin alınmadı̆̆ı takdirde zarar verme olasılığının yüksek olduğu durumlarla birlikte, önerilen tavsiyenin etkililiği ve alıcının öz yeterliliği yüksek olduğu zamanlarda koruma güdüsü oluşturduğunu ortaya koyan "koruma motivasyonu modeli“ ile ilişkilendirilmiştir.

"Domestos Maksimum Hijyen" reklamında görüntüde ilk olarak büyük ekranda verilen mikrop görüntüsü dikkat çekmektedir. Daha sonra görüntü geniş açıyla ele alınarak etrafında sayısız mikropla birlikte gösterilmiştir. Yan yana verilen iki ayrı görselde tuvaletlerin birinde diğer bir ürün, öbüründe ise Domestos'un kullanıldığının görüntüsü verilmiştir. Domestos'un yeni formülünün sadece mikropları öldürmediği aynı zamanda kireç oluşumunu üç kata kadar daha uzun süre önlediği vurgulanmıştır. Mikropların üzerine gelen Domestos ile birlikte tüm mikropların yok olduğu ekrana yansımış "Yeni Domestos Mikropları Öldürür, Kireci Üç Kata Kadar Daha Uzun Süre Önler” sloganı ile reklam sonlandırılmıștır.

Reklam gösteren açısından değerlendirildiğinde ekrana sayısız mikrobun yansıması dikkat çeken ilk korku unsurudur. Bununla beraber Domestos ile temizlenen tuvaletin temizliği simgeleyen beyaz ile gösterilerek bir bașka ürün kullanıldığı takdirde ise sarı ve gri renklerin yoğunlukta olduğu kirli ve kireçli tuvalete maruz kalınacağı görüntüsü bir diğer korku unsurudur. Yayılan Domestos ile yok olan mikroplar gösterilmiş çözümün etkinliğine vurgu yapılmıştır.

Reklamda Domestos kullanılmazsa kireç oluşumunun artacağı ve mikropların yayılacağı üzerinde durulmuştur. Bu probleme çözüm olarak önerilen Domestos şişesinin kolay kullanılabilir başlığı ile öz yeterlilik oranı arttırılarak ürünün satın alınması amaçlanmıştır.

\subsection{Calgon "Calgon'un Kir Önleyici Aktifleri İș Başında” Reklam Analizi}

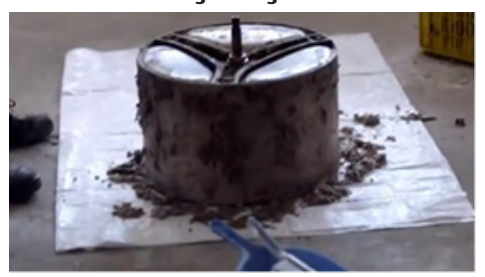

Şekil 2. Calgon "Calgon'un kir önleyici aktifleri iş başında" reklam örneği

2018 yılında yayına giren “Calgon’un Kir Önleyici Aktifleri İş Başında” reklamında çamaşır makinesinden çıkan kir korku unsuru olarak kullanılmış, "Bunu engelleyebilirsiniz" ifadesi ile verilen mesajla öz yeterlilik oranı yükseltilmeye çalışıldığından ele alınan reklam "koruma motivasyonu modeli" ile ilişkilendirilmiştir. 
Reklamda çamaşır makinesinden çamaşırları makinenin lastiğinde biriken kirlere değdirmeden çıkarmaya çalışan bir kadın ile ona yardım eden bir erkek görülmektedir. Yorulduğunu ifade eden kadının görüntüsünün ardından ekrana çamaşır makinesi tamircisi girmekte bu kirin sadece makinenin görünen kısmı olduğunu belirterek çamaşır makinesinin kazanından bir yılda çıkan yarım kilo kiri göstermektedir. "Bunu engelleyebilirsiniz her yıkamada Calgon kullanın” ifadesiyle Calgon'un formülündeki kir önleyici aktiflerin kiri ve kireci engellediğini elindeki beyaz bezi çamaşır makinesinin lastiğini silerek "Temiz makine, temiz çamaşırlar" ifadesiyle temizliği kanıtlamaya çalışmıştır. Bundan daha sonraki karede reklam "Makineniz Uzun Yaşar Calgon'la” sloganı ile sonlandırılmıştır.

Reklamda kadın oyuncunun çamaşır makinesinde biriken kiri işaret etmesi ve çamaşır makinesi tamircisinin çamaşır makinesi kazanında biriken yarım kilo kiri belirtmesi korku unsuru olarak gösteren niteliğinde değerlendirilmektedir.

Reklamın başlangıcında kadın oyuncunun yüzündeki yorgunluk ifadesi ve kazandan çıkan kir görüntüde korku unsuru olarak kullanılmıştır. Arka planda verilen eski, kırılmış ve bozulmuş makinelerle tehdit unsurunun yoğunluğu arttırılmıștır. Tavsiye edilen ürünün ekrana getirilmesinin ardından sonra tamirci, beyaz bez ile çamaşır makinesinin lastiğini silmiştir. Bezin temizliği gösterildikten sonra ise "lider makine üreticilerinin tavsiyesi" alt yazısı ile reklam sonlandırılmıştır. Ses açısından gösterilen değerlendirildiğinde kadın oyuncunun "yoruldum artık" ifadesi ile çamaşır makinesinden çıkan eşyalarının temiz çıkmadığını, makinenin kirlenmesinin sürekli olarak tekrarlandığını belirtmiştir. "Bu sadece kirin görünen yüzü" ifadesi ile birlikte tedirginlik oluşturulmuştur. Makinenin kazanından çıkan kiri tamircinin yere sert bir şekilde vurmasıyla çıkan ses açısından korku unsurunun arttırılmaya çalışıldığı söylenebilmektedir.

Reklamda verilen çamaşır makinelerinin kirli görüntüsü verilmiş eğer Calgon kullanılmazsa arka planda verilmiş olan makineler gibi kir ve kireç yüzünden bozulacağı gösterilerek korku yaratılmaya çalışılmıştır. Reklamda verilen "her yıkamanızda kullanın" ifadesiyle aslında çözümün basit ve kolay olduğu vurgulanarak tüketicinin öz yeterlilik algısı arttırılarak ürünün satışının yapılması amaçlanmıştır. Ürünü satın alan tüketicinin böylece çamaşır makinesini uzun yıllar boyunca kullanabileceği belirtilerek tehdit unsurunun ortadan kalkacağı ifade edilmeye çalışılmaktadır.

\subsection{Allianz "Yola Her Çıktığında \#AllianzSeninle" Reklam Analizi}

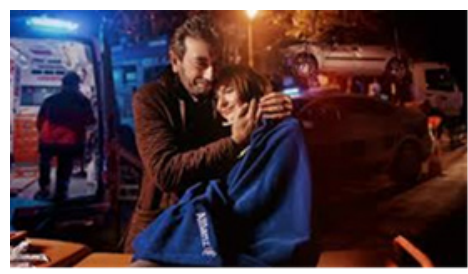

Şekil 3. Allianz "yola her çıktı̆̆ında \#allianzseninle" reklam örneği

2018 yılında yayınlanan Allianz "Yola Her Çıktığında \#AllianzSeninle" reklamı tehdit unsurunun yüksek verilmesi nedeniyle "genişletilmiş paralel işleme modeli" ile ilişkilendirilerek ele alınmıştır.

Reklam baba kızın sahilde yürümesiyle başlamaktadır. Akış, kızın babasına neden düşünceli olduğunu sormasıyla devam etmiştir. Kızından hiç ayrı kalmadığını ifade eden babanın, kızının doğumundan başlayan yetişkinliğine kadar devam eden zamanların 
aklına geldiği görüntülerle yansıtılmıștır. Ekrana bu düşüncelerin yansımasıyla beraber aynı zamanda kızın kaza yapması, taklalar atarak yoldan çıktığı gösterilmiştir. $\mathrm{Bu}$ sahnenin üzerine kızını özleyeceğini ifade eden babanın sesi eklenerek verilmiştir. $\mathrm{Bu}$ sahneden sonra kız arabayı tek parça halinde geri getireceğini ifade etmiş, kazadan kurtulan kızın sedyede babasına sarıldığını görüntüsü verilmiştir. Birbirine sarılan baba kızın yüzlerindeki korku ve endişe ekrana yansımıştır. Babanın kazanın geçmişte kaldığını belirtmesi, "hiçbir şey senden kıymetli değil" cümlesini kurması ile birlikte reklam "Yola Her Çıktığında Allianz Seninle ve Sevdiklerinle” sloganıyla sonlandırılmıştır.

Reklamda kızın arabayla kaza yapması, taklalar atarak yoldan çıkması bununla beraber ambulans ışıklarının gölgesi altında geçirdiği kazanın korkusuyla yüzüne yansıyan tedirgin ifadesi korku unsuru; babanın ağlayan ifadesi ise tehdit ögesi olarak ele alınarak gösteren olarak değerlendirilmiștir.

Reklam görüntü açısından değerlendirildiğinde kaza anında araç içerisinde olan kadının görüntüsü korku çekiciliği unsurudur. Korku derecesi yüksek olan bu görüntünün ardından kaza anında uçuşan kuşlar bir başka korku ögesidir. Kazanın ardından ekrana yansıyan ambulans, polis arabası ve dağılan arabanın görüntüsü korku çekiciliği unsurunun kullanıldığı bir diğer sahnedir. Reklam ses açısından değerlendirildiğinde kullanılan müziğin izleyeni duygusal bir hale getirerek korku unsurunun etkililiğinin arttırılmaya çalışıldığı görülmektedir. Kaza anında kadının attığı çığlıkla beraber fren sesinin duyulması ve takla atan aracın çarpma sesi yüksek oranda korku unsurunun kullanıldığı sahnelerdir.

Reklamda hayatın hiçbir şeyden daha önemli olmadığı vurgulanarak beklenmeyen bir anda gelen kaza ile korku oluşturulmaya çalışılmıştır. Korku unsuruna cevap olarak Allianz Sigorta önerilmiş kaza sonrasında Allianz'ın kazazedeyi koruyacağı böylece tehdit unsurunun ortadan kalkacağı belirtilmiştir.

\subsection{Veet "Değer Mi Hiç" Reklam Analizi}

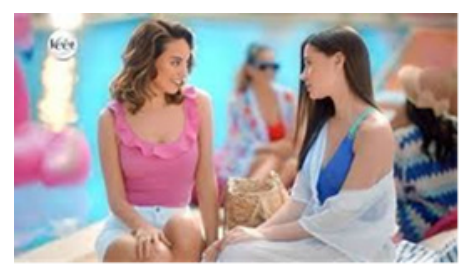

Şekil 4. Veet "değer mi hiç" reklam örneği

2018 yılında yayınlanan Veet reklamı korku unsuru çok fazla barındırmadığı ve reklamda tedirgin eden mesajların bulunması nedeniyle "Thayer'in tahrik modeli" ile ilişsilendirilmiştir.

Reklamda oyuncu Seda BAKAN rol almış ve Sezen AKSU’nun seslendirdiği “Değer mi hiç?" şarkısı kullanılmıştır. Üç ayrı platformda üç farklı Veet reklamı çekilmiştir. İlk reklam havuz kenarında, ikinci reklam spor salonunda, üçüncü reklam ise fotoğraf çekiminin yapıldığı bir stüdyoda geçmektedir. İlk reklamda kadın istenmeyen tüyler nedeniyle kendini kötü hissetmekte, tüylerinin kalınlaştığını ifade etmektedir. Seda BAKAN "Değer mi hiç?" şarkısı ile sahneye girmekte "tüylerinin sertleşip kalın göründügünü düşünüyorsan neden tıraş bıçağı kullanıyorsun? "Veetlesene!" diyerek elindeki tıraş bıçağı aşağı indirmekte "Veet sir ağda bantlarının «Easy Silk' teknolojisi ile bu soruna çözüm getirdiğini ifade etmektedir. İkinci reklamda ise bir başka kadının spor yaparken aynı problemi yaşaması üzerine olduğu yerden ayrıldığı gösterilmektedir. Seda Bakan 
bu sahneye yine "Değer Mi Hiç?" şarkısına eşlik ederek girmekte “Tüylerinin ertesi gün çıktığını düşünüyorsan neden tıraş bıçağı kullanıyorsun? "Veetlesene!” sloganını atarak Veet'in tüy dökücü kremini göstermektedir. Son reklamda ise fotoğraf çekimindeki kadın oyuncunun bacağındaki yara bandını gizlemeye çalıştığı görülmektedir. Seda Bakan sahneye burada aynı jingle ile girmekte "cildinde kesik ve çiziklere sebep olduğunu düşünüyorsan neden traș bıçağı kullanıyorsun? Veetlesene!” ifadesini kullanmaktadır. Bu sahnenin ardından Veet tüy dökücü spreyin etkisi gösterilmektedir. Tüm bu reklamlar 10 kadından 9>unun Veet'i önerdiğini belirtilmesi ile birlikte son bulmaktadır.

Reklamda gösteren olarak ilk reklamda kullanılan gülün dikeni, ikinci reklamda istenmeyen tüyler ve son reklamda ise yara bandı kullanılarak tedirginlik oluşturulmaya çalışılmıştır. Gösterilen, görüntü açısından değerlendirildiğinde kadınların yaşadıkları olumsuzluk karşısında yüzlerindeki tedirginlik ifadesi, bu durum nedeniyle bulundukları ortamı terk etmeleri, gizlenmeye ya da vücudunu saklamaya çalışmaları, bu nedenle içinde bulundukları toplumsal ilişkilerde problem yaşayacaklarının ifade edilmeye çalışıldığını söyleyebiliriz.

Reklamda kadınların tıraş bıçağı kullanmaları nedeniyle yaşadıkları olası problemler belirtilerek tedirginlik oluşturulmuştur bu yolla çeşitli ürünlerle farklı problemlere yönelik cevap verilerek ürünün satışı amaçlanmıştır.

\subsection{AXA Sigorta "Tutumlu Kasko Sigortası" Reklam Analizi}

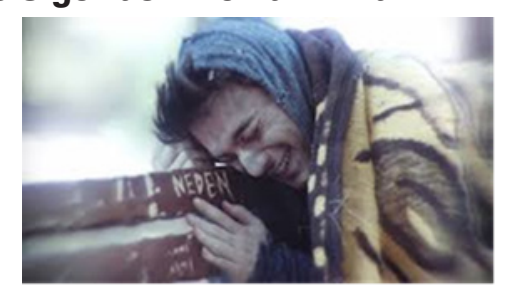

Şekil 5. AXA Sigorta "tutumlu kasko sigortası" reklam örneği

2018 yılında yayınlanmış olan Axa "Tutumlu Kasko Sigorta" reklamı içerisinde tehlike unsurları ile birlikte korku unsurlarını barındırması açısından "paralel tepki modeli“ ile ilişkilendirilmiştir.

Reklam adamın park ettiği aracı yerinde bulamaması ile başlamaktadır. 0 anda arabasını bulamayan adamın aklından arabasının çalındığını geçmektedir. Ardından aklına polisin gelip tutanak tutarken kasko yaptırıp yaptırmadığını soracağını, eşini haber vermek için aradığında eşinin de neden kasko yaptırmadığını sorgulayacağını, çalıştığı yere gittiğinde iş arkadaşlarının nasıl olurda kasko yaptırmadığını soracaklarını düşünmektedir. İş arkadaşlarına çok pahalı olduğunun serzenişinde bulunan adama iş arkadaşı elindeki broşürü göstererek kaskoların pahalı olanın yanında hesaplı olan kaskoların da olduğunu söylemekte, Axa'nın tutumlu kasko sigortasının \%30 fiyat avantajına sahip olduğunu belirtmektedir. Daha sonra ekrana adamın orman içinde tek başına kalmış hali getirilmekte, adam yıllar geçse bile kendini affetmeyeceğini belirtmektedir. Yüzüne pişmanlık ifadesi yansıyan adam kendini sorgulamaktadır. Bu sırada sahne aracın park edildiği alana döner ve arka kapıdan bir kişi çıkar ve adama seslenerek arabasının çekildiğine söyler. Bu haberi alan adamın yüzü gülmektedir. Sonrasında "Kıymetini Kaybetmeden Bilenlere" ifadesi ile reklam devam ettirilmektedir. Akabinde ekranda "tutanak ile ya da tutanaksız tüm hasarlarınızda, 'garantili servislerimizde yedek parça ve işçiliğe tam iki yıl garanti" yazısı akmaktadır. Reklam "Dert Varsa Derman Axa" sloganı ile son bulmaktadır. 
Reklamın göstergebilimi tekniği analizinde ise, görüntü açısından değerlendirildiğinde oluşturulan korku çekiciliği unsurlarından ilki, park edilen aracın yerinin boş olarak yansıtılmasıdır. Ayrıca araç sahibinin o an yüzündeki korku ve endişe ifadesi kullanılan korku unsurlarından birisidir. Polisin, eşinin ve iş arkadaşlarının karşısında yaşadığı tedirginlik ifadesi tehlike unsuru olarak kullanılmıştır. Ormanda tek başına elinde sadece arabanın anahtarı ile kalan adamın ağlamaklı ifadesi bir başka tehlike unsuru olarak görülmektedir. Ses açısından değerlendirildiğinde polisin, eşinin ve iş arkadaşlarının neden kasko yaptırmadığını sorgulamaları, adeta bir korku filmini hatırlatır orman sahnesinde trafik sesleri, fren sesleri, alarm sesleri korku unsurları olarak kullanılmıștır. Kendine kızan adamın "Neden!" diye çı̆̆lık atması ise bir başka korku unsurudur.

Ele alınan reklamda amaç; kasko yaptırılmazsa yaşanılan herhangi bir olumsuz durum karşısında çaresiz kalınacağı gösterilerek korku unsurlarının oluşturulması olarak ifade edilebilir. Böyle bir duruma düşmeden tüketiciye Axa Tutumlu Kasko yaptırması önerilmiş, kasko yaptırıldığı takdirde sorunların ortadan kalkacağı gösterilmiştir.

\subsection{Fnish "Suyun Sonu Görünüyor" Reklam Analizi}

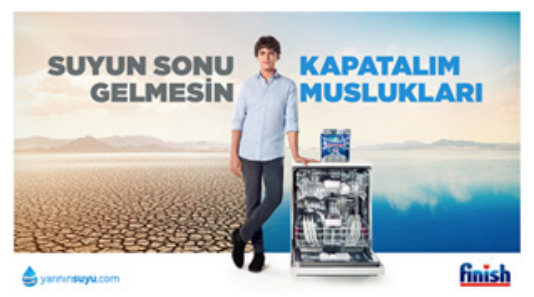

Şekil 6. Fnish "suyun sonu görünüyor" reklam örneği

2019 yılında yayınlanan ve bireylerin mesajın taşıdığı korku unsurunu değerlendirdiğinde ne kadar çok ciddi bir tehditle karşı karşıya kaldıklarına inandırılması açısından korku çekiciliği modellerinden Genişletilmiş Paralel İşleme Modeli ile ilişkilendirilen Fnish Suyun Sonu Görünüyor" reklam çalışmasında tüketicide su kaynaklarının azalmasına yönelik korku unsuru oluşturulduğu tespit edilmiştir.

Reklamda, Taner Ölmez oynatılmış ve Yolun Sonu Görünüyor şarkısından esinlenerek suyun sonu görünüyor şeklinde şarkı kullanılmıştır. Reklam Kars Kuyucuk Gölünden çekilmiş ve görüntüde su kaynağının kuruyarak çölleştiği gösterilmiştir. Daha sonraki kısımda ise bulaşık yıkayan bir annenin ve ona yardım eden oğlunun görüntüsü sunulmuştur. Arka planda ise birikmiş bulaşıklar ve sürekli olarak musluktan akan su gösterilmektedir. Çalışmada Türkiye'nin su fakiri olma riski ile karşı karşıya olduğu ama bulaşıkların sudan geçirilmesi bırakılarak makinede yıkandığında her yıkamada 57 litre su tasarrufu sağlanacağı böylece her sene Kuyucuk'un 40 katı suyun kurtarılabileceği anlatılmıştır. Musluk kapatıldığında ise oluşan mutlu insan figürü kullanılmıştır. Reklam Taner ÖLMEZ'in musluğu kapatarak “Fnish Quantum varken bulaşıkları sudan geçirmeye ne gerek var kapatalım muslukları suyun sonu gelmesin” sözleriyle tamamlanmıștır.

Çalışmanın gösteren kısmında Kars Kuyucuk Gölü'nden kuruyan su kaynağı ve bulaşık yıkarken oluşan su israfı; gösterilen kısmında ise bulaşıkların elde yıkanarak çok ciddi bir oranda su tüketimi yapıldığı ve bu duruma paralel olarak su kaynaklarının kuruyarak ülkemizin susuz kalma tehdidi ile karşı karşıya olduğu korku çekiciliği unsurları kullanılarak aktarılmıştır.

Reklamın göstergebilim analizinde hem görüntü hem de sözlü kısmında yoğun olarak korku çekiciliği unsurlarının kullanıldığı görülmektedir. Görüntü kısmında 
Taner ÖLMEZ'in yüz ifadesinin endişeli ve korku içerisinde olduğu bu durumun da su kaynağının tükenmesine bağlı olduğu reklamda yansıtılan korku çekiciliği ibarelerinden biridir. Kuyucuk Gölü'nün geniş açllı tamamen kuruyarak çölleşmiş görüntüsü de reklamda kullanılan başka bir korku çekiciliği unsurudur. Suyun gereksiz yere israf edilerek kaynakların tükendiği mesajı verilmiş ve gölün kurumuş görüntüsü üzerinden korku oluşturulmuştur. Ayrıca bulaşık yıkama esnasında kullanılan suyun fazla akıtılarak yansıtılması suyun tüketimi noktasında hedef kitleye tehdit unsuru olarak gösterilmiștir. Reklam çalışmasının sözlü kısmında ise daha net ve belirgin korku ögeleri kullanıldığı tespit edilmiştir. Şarkı sözlerinin değiștirilerek "suyun sonu görünüyor" șeklinde insanlara sunulması ile temel yaşam kaynağı olan suyun sonunun geldiği noktasında hedef kitle de korku yaratmak amaçlanmıştır. Reklamda kullanılan "Türkiye su fakiri olma riski ile karşı karşıya” söyleminde de Türkiye'nin ileride su kaynağı temin etme noktasında büyük bir tehdit ile karşı karşıya olduğunu vurgulayarak korku oluşturduğu görülmektedir. Kullanılan "Kapatalım Muslukları Suyun Sonu Gelmesin” sloganı ile de tüm reklamın ana temasının oluştuğu suyun tükenmesi konusuna sloganda da dem vurulduğu ve slogan yolu ile de korku oluşturulduğu söylenilebilmektedir.

Reklamın temel amacı bulaşıkların elde yıkanmaya devam ettiği sürece ülkenin su kaynaklarının giderek azaldığı noktasında tüketicide korku yaratmak, hatta su kaynaklarının tamamen kuruyacağı yönünde tehdit unsurları oluşturmaktır. Reklamda öncelikle tüketiciye korku verilmiş çözüm önerisi olarak ise Fnish'in kendi ürününü sunduğu görülmüştür. Fnish Quantum ürünü mevcutken bulaşıkları elde yıkamaya gerek olmadığı böylece ciddi tasarruf sağlanarak su kaynakları yönünden de korku ve tehdit unsurunun ortadan kalkacağı tüketiciye aktarılmıştır.

\subsection{Rexona "Sarı Lekelere Son" Reklam Analizi}

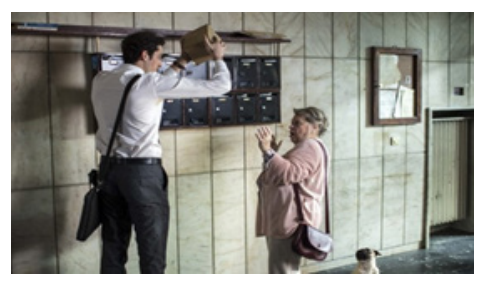

Şekil 7. Rexona "sarı lekelere son" reklam örneği

2019 yılında yayınlanan "Rexona Sarı Lekelere Son" reklam filmi korkunun, hoş olmayan bir durumdan bireyleri kurtarmak için motive etmeye yönelik kullanıldığının görülmesi ayrıca mesajın yeterince korku uyandırarak alıcıda duygusal gerginlik oluşturması bakımından korku çekiciliği modellerinden "itki modeli" ile bağdaștırılmıștır.

Çalışmanın gösteren kısmında beyaz gömleğin kol altı bölgesinde oluşmuş kötü görünen sarı lekeler yansıtılmıştır. Gösterilen kısmında ise beyaz giysilerde oluşan ve görünümüyle kirlilik hissi uyandıran sarı lekenin bulunulan her ortamda insanların kaçarcasına endişe ile bakması, sert reaksiyonlar vererek uzaklaşması ve bunun ile birlikte bireyin düştüğü zor durum yansitılmıştır.

Reklam filminde gösteren ve gösterilen unsurlarının tespit edilmesinden sonra çalışma taşıdığı korku ögeleri bakımından analiz edildiğinde, reklamda, sabah beyaz gömleği ile evinden çıkan genç bir adamın koltuk altı bölgesinde oluşan sarı leke ile mücadelesi anlatılmaktadır. İlk başta genç adam evinden çıktığında yardım etmek istediği komşusunun ve onun köpeğinin sarı lekeleri görmesiyle adam kendinden uzaklaşıldığını fark ediyor ve onların korku dolu bakışlarıyla karşılaşıyor. Ardından otobüse binen 
genç adam, kolunu tutunmak üzere kaldırdığında, otobüste bebek de dahil olmak üzere tüm yolcuların ondan nefretle uzaklaşırcasına korku ve endişe dolu tepkilerine maruz kalmaktadır. İş yerine geldiğinde ise sunum esnasında sarı lekenin görülmesi sonucu yine tüm çalışanlarca aynı muameleyi görmektedir. Günün sonunda kız arkadaşı ile akşam yemeği yemek için gittiği restoranda da sarı lekeler başına dert olmaya devam etmekte ve başta kız arkadaşı olmak üzere tüm restoranın huzursuz olduğunu ve her şeyin kendisi yüzünden yerle bir olduğunu gözlemlemektedir. Ayrıca reklamda korku çekiciliği unsurunun kullanımını abartmak için kişi otobüsten indiğinde kokudan rahatsız bir figür yansıtan reklam çalışması da kullanılmıștır. Reklam boyunca arka planda çalan müziğin bulunulan ortamları daha gergin halde yansıtmak için kullanıldığı ve böylece sunulan korku çekiciliğinin boyutunun artırılmaya çalışıldığı görülmüştür. Reklamın sonunda ise adam garson tarafından "Sarı Lekelere Karşı Rexona kullan" sloganı ile uyarılmaktadır. Bu slogan ile sarı lekelere karşı çözümün Rexona ile mümkün olabileceği anlatılmak istenmiştir. Nitekim adamın Rexona kullanmaya başlaması ile bu sorundan kurtulduğu gösterilerek slogan desteklenmiştir. Reklamın genelinde ana karakterin gömleğinde oluşan lekelerden insanların ciddi anlamda rahatsız olduğu, hızla ondan uzaklaşıldığı ve nefret dolu ifadelerle kendisine bakıldığı görülmüş ve kişinin böylece istenilmeyen, hoş görülmeyen biri olarak toplumdan dışlanabileceği yansıtılmıştır. Benzer durumda olan insanların aynı tepkiye maruz kalacağı ve kendilerine bakış açılarının da bu yönde olacağı noktasında tüketici de derin biri korku unsuru oluşturulmaya çalıșılmıştır.

Reklamın göstermek istediği unsurları özetleyecek olursak deodorant kullanılmadığında ya da kullanılan diğer ürünlerde beyaz kıyafet giyinildiği zaman istenmeyen lekelerin oluşabileceği ve çevremizin bundan rahatsız olarak bizden uzaklașabileceği düşüncesini yansıtmaktır. Bireyin tüm çevresinin ondan uzaklaşması ile toplum tarafından dışlanma düşüncesi ile tüketicide korku oluşturulmuştur. Rexona çıkardığı "İnvisible Black White" ürününü reklam filminde çözüm önerisi olarak sunmuştur. Rexona kullanarak sarı lekelerin önüne geçilmesinin mümkün olduğu ve herhangi korku ve endișe duymaya gerek olunmayacağı hedef kitleye aktarılmıștır.

\subsection{Axa "Cep Telefonu Sigortası" Reklam Analizi}

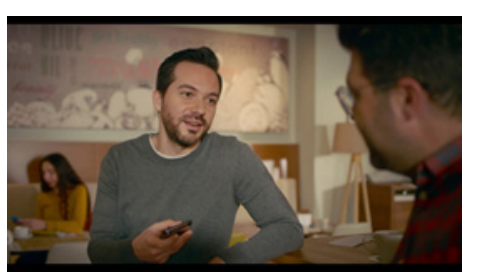

Şekil 8. Aха "cep telefonu sigortası" reklam örneği

2019 yılında yayınlanan "Axa Cep Telefonu Sigortası" reklam filminde bireyin davranışının değişmesi için bir tür uyarıcı tehdit etkisi alması ve uyarılmanın gerginlik yaratacak bir boyutta sunulması, tüketiciyi uyandırmaya yönelik duygusal tepkilerin verilmesi nedeniyle çalışmada sunulan korku çekiciliği mesajları Thayer tahrik modeli ile ilişkilendirilmiştir.

Reklam filmi kafede oturan iki arkadaş arasında geçmektedir. Oyunculardan birisi yeni son model pahalı bir telefon almıştır ve telefonunu arak adaşına gösterirken elinden düşürerek kırmıştır. Kırılan telefonun kaskosu bulunmamaktadır. "Cep Telefonunuzu Axa İle Sigortalayın ve Kıymetini Kaybetmeden Bilin” sloganı ile reklam tamamlanmıștır. 
Reklam filminde gösteren olarak düşerek parçalanan cep telefonu gösterilen kısmında ise pahalı ve değerli eşyalarınızın sigortası yoksa onların başına herhangi olumsuz durum geldiğinde yapılan tüm harcamaların boşa gideceği bu nedenle üzülmemek için onları sigorta ile koruma altına almamız gerektiği fikri iletilmeye çalışılmıştır.

Reklamın görüntü kısmında korku çekiciliği mesajları yere düşen ve parçalanan telefon ile sağlanmıştır. Yeni alınan ve oldukça pahalı olan bir cep telefonu yere düştüğünde kullanılmayacak derecede hasar görmesi ve bunun ekranlara yansıtılması ile oluşacak durum üzerinden korku oluşturulmuştur. Ayrıca reklamda oynayan oyuncuların telefon yere düştükten sonra yüz ifadelerindeki jest ve mimiklerinde korku ve üzüntülü bir hal aldığı görülmektedir. Korku çekiciliği yüz ifadeleri ile desteklenmiş ve tüketiciye sizde cep telefonunuzu sigortalatmazsanız bu şekilde üzülür ve pişman olursunuz mesajı verilmek istenmiştir. Reklamın sesli kısmında ise korku anlatıcının sözleriyle sağlanmıştır. Gergin ve ortamdaki korkuyu pekiştirecek bir ses tonu ile "telefonu düşürmek hele ki kırmak hayatınızda kritik bir hataya sebep olabilir" sözü ile tüketiciye korku çekiciliği içeren mesaj verilmiştir. Cep telefonunu düşürmek ve özellikle de buna bağlı olarak ürünün kırılması insanın yaptığı büyük bir hata ve paralelinde başına gelecek maddi anlamda bir felaket olarak yansıtılmış ve izleyicide korku oluşturmak amaçlanmıştır.

Göstergebilim analizinde reklamın temelde sunmak istediği oldukça yüksek meblağa aldığımız bir cep telefonunun elimizden düşerek kırılmasının son derece mümkün olduğu ve telefonun herhangi sigorta güvencesi yoksa verilen tüm paranın boşa gideceği gösterilmiştir. Reklam filminde telefonun bir anlık dikkatsizlikle kullanılmaz duruma geleceği parçalanmış bir cep telefonu görüntüsü ile ve bu durumun başımıza açabileceğimiz ciddi bir hata olduğu sözlü ibarelerle korku uyandırılarak anlatılmıştır. Axa çözüm önerisini reklamın içerisinde "Gelin Siz Kıymetini Kaybetmeden Bilin Cep Telefonunuzu Axa Sigortası Güvencesi Altına Alın” sözleriyle vermiştir. Hitap ettiği hedef kitlenin cep telefonları kendi ürünleriyle sigortalandığı zaman onların herhangi bir endişe yaşamasını gerektirecek bir durumun olmadığı aktarmıștır. Ayrıca bu tarz dertlerin çözümü olarak "Dert Varsa Derman Axa” reklam sloganı kullanmıştır.

\subsection{Rexona "Tıkalı Burunlar" Reklam İncelemesi}

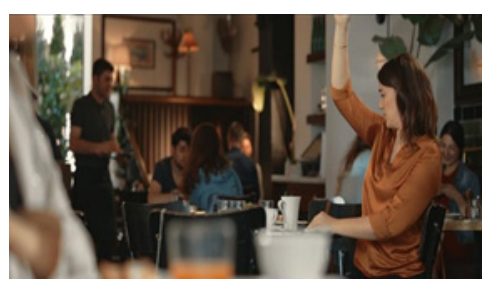

Şekil 9. Rexona "tıkalı burunlar" reklam örneği

2019 yılında yayınlanan "Rexona Tıkalı Burunlar" incelenen diğer Rexona reklamında olduğu gibi korkunun, hoş olmayan bir durumdan bireyleri kurtarmak için motive etmeye yönelik kullanıldığının görülmesi ayrıca mesajın yeterince korku uyandırarak alıcıda duygusal gerginlik oluşturması bakımından korku çekiciliği modellerinden "itki modeli" ile bağdaştırılmıştır.

Reklam filminde gösteren olarak gömleğin kol altı kısmında oluşmuş ter görüntüsü verilmiştir. Gösterilen kısmında ise giysilerde oluşan ve negatiflik hissi uyandıran ter görüntüsü ve onun yaydığı kötü koku yüzünden diğer insanlar üzerinde oluşturabileceğimiz olumsuz etki aktarılmıștır. Bu durum yüzünden ise insanların burunlarının tıkanırcasına rahatsız olduğu ve ter kokan kişiden uzaklaşılacağı gösterilmek istenmiştir. 
Reklam filminde yansıtılan korku çekiciliği mesajları incelendiğinde reklamda arkadaşları ile buluşmak için kafeye gelen genç bir kadının terlemeden dolayı çektiği sorun anlatılmaktadır. Kadın sipariş vermek için kolunu kaldırdığında arkadaşlarınca terlediği fark edilir yayılan kötü kokudan tüm arkadaşları rahatsız olmuş ve hepsinin kokudan burunları tıkanmıştır ve tıkalı burun ile konuşmaya başlamışlardır. Her biri bir bahane ile masadan kaçar ve kadın yalnız kalır ve ter kokusundan dolayı herkesin gittiğini fark eder. Böylelikle terlerden dolayı toplumda istenmeyen ve arkadaş çevresince terk edilen, herkesin yanından kaçtığı dışlanmış kişi imajı ile korku oluşturulmuştur. Ayrıca koltuk altında oluşan ter kısmının detaylı gösterilmesi ve bunu gören kişilerin yüzünde oluşan tiksinme ifadesi ile de reklamda korkunun boyutunun artırıldığı, izleyicilerin terin oluşturduğu tehdit durumuna karşı uyarıldığı tespit edilmiştir.

Korku çekiciliğinin işlendiği sözlü kısım ise sanatçı Orhan Gencebay’ın yer aldığı sahnede yansıtılmıştır. Orhan Gencebay kadının yanına gelerek "duş yetmez ben kokmam deme arkadaşlığın selameti için duştan sonra Rexona kullan" diyerek hedef kitleye sadece duş almanın kokmamaya ve terlememeye çözüm olmayacağı ve bu durumda arkadaş çevremizce yalnız bırakılabileceğimiz hususunda korku mesajları verilmiştir.

Reklamın iletmek istediği düşünce en temel anlamda duştan sonra deodorant kullanılmadığında vücutta ter oluşabileceği ve bu terlerin hem kıyafet üzerinde kötü bir görüntüye hem de kötü bir kokuya neden olacağıdır. Bu durum kişinin bulunduğu ortamdaki tüm tanıdıklarının ondan rahatsız olarak uzaklașması dolayısıyla ter kokan birisinin çevresi tarafından dışlanacağı, istenmeyeceği düşüncesi ile izleyiciler üzerinde korku oluşturulmuştur. Bu duruma çözüm olarak Rexona deodorant kullanımı önerilmiştir. Rexona deodorant kullanılarak ter oluşumunu engellenmesinin mümkün olduğu ve herhangi korku duymadan rahatça ortamlara girilebileceği aktarılmıştır.

\subsection{Ziraat Sigorta "Hayatta Her Türlü Risk Var" Reklam Analizi}

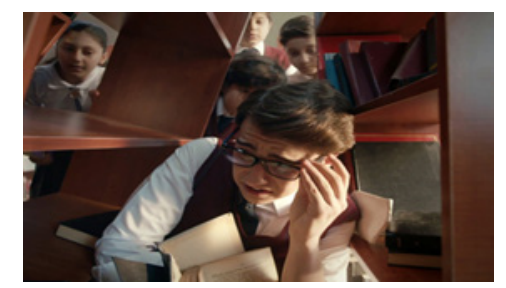

Şekil 10. Ziraat Sigorta "hayatta her türlü risk var" reklam örneği

2019 yılında yayınlanan Ziraat Sigorta reklam filminde yıllar boyunca her alanda artarak tehdide maruz kalan insanlar yansıtılmıștır. Bu durumda bireyler mesajın taşıdığı korku unsurunu değerlendirir ve ne kadar çok ciddi bir tehditle karşı karşıya kaldıklarını görmektedir. Tehdit durumunun ciddi ve geniş çaplı olması nedeniyle bu reklam filmi korku çekiciliğinin "genişletilmiş paralel işleme modeli" ile ilişkilendirilmiştir.

Reklamda gösteren olarak bireyin yaşam çevresinde başına gelebilecek zaralar gösterilen kısımda ise bireyin yaşamının her anında ve her yerde ummadık şekilde riskler ve felaketler yaşayabileceği ve bu durumdan ciddi zararlar görebileceği yansıtılmıștır.

Reklamda korku unsuru evin küçük çocuğun ufak yaşlardan başlayarak büyümeye devam ettiği yıllarda dahil olmak üzere evden işyerine; okuldan taşıta kadar açtığı zararlar üzerinden sağlanmıștır. İlerleyen yıllar içerisinde top ile oynarken evin eşyalarını kırması, su ile oynarken evin su basmasına sebebiyet vermesi, iş yerinde ofis ekipmanlarına hasar vermesi, okulda kütüphane ekipmanına zarar vermesi ve ağabeyinin bu durumdan 
sağlık yönünden de hasar görmesi en sonunda ise babasının gözü gibi baktı̆̆ı motoru parçalaması korku çekiciliğinin işlendiği tehdit unsurlarıdır. Reklamda işlenen sözlü korku çekiciliği mesajı ise "Hayatta Her Türlü Risk Var" sloganıdır. Görüntülerin ve bunlarla birleștirilen sloganın vermek istediği mesaj yaşamımızı sürdürdügümüz her alanda her türlü beklenmedik tehlikelerin başımıza gelebileceğidir.

Reklam filminde insanın başına gelen olumsuz durumların ve bu durumların onları ne gibi tehditlerle karşı karşıya bıraktığı yansıtılmıştır. Hayatın her anının risklerle dolu olduğu ve insanların beklenmedik kazalarla ciddi şekilde maddi ve manevi hasarlar görebileceği anlatılmış ve böylelikle hedef kitle üzerinde korku oluşturulmuştur. Çözüm olarak ise bu durumlarla karşı karşıya kaldığımızda zarar görmemek için güvenceye ihtiyaç duyulduğu ve Ziraat Sigorta'nın araçtan konuta; sağlıktan iş yerine kadar ihtiyaç duyulan her alanda insanların yanında olduğu belirtilmiştir.

\section{Sonuç}

Reklamlar insanları ikna ederek onların satın alma davranışına doğrudan etki eden çok etkili silahlardır. Reklamlarda insanları ikna etmek ve onlarda ürünü kullanmaya yönelik istek uyandırmak için birçok metot uygulanmaktadır. Bu metotlardan birisi de insanları korkutma yoluyla satın alma davranışında bulundurma yöntemidir. İnsanların tedbir almadıkça başlarına gelebilecek olumsuz olaylar, felaketler korku ya da tehdit yoluyla izleyiciye sunulur ve hedef kitlenin bu durumu yaşamaması için ürünleri satın alma isteği uyandırılmaya çalışılır. Bu durum reklamların ikna teknikleri için kullandığı çekicilik türlerinden korku çekiciliği olarak adlandırılmaktadır. Korku çekiciliği en genel ifadeyle verilmek istenen mesajların insanlar üzerinde razı gelme davranışı bırakması amacıyla onları korku ve tehdit yoluyla etkilemeye çalışan reklamları kapsamaktadır.

Bu çalışma ünlü dil bilimci Ferdinand de Saussure' ün gösteren ve gösterilen düzlemleri üzerinden göstergebilim metoduna dayandırılarak televizyon reklamlarında yayınlanmış ve içerisinde korku çekiciliği mesajları barındıran reklam incelemelerini konu almıştır. Çalışmada incelenen örneklemler korku çekiciliğinin taşıdığı anlamlar bakımıyla konunun iskeletini oluşturan beş temel korku çekiciliği modeli olan İtki modeli, paralel tepki modeli, Thayer tahrik modeli, koruma motivasyonu modeli, genişletilmiş paralel işleme modellerinin her birine uygun olarak seçilmiştir. İncelenen örnekler neticesinde reklamların korku çekiciliği kullanım yöntemleri tespit edilmeye çalışılmıştır.

Korku çekiciliği içeren mesajlar insanlara, reklamlarda anlatılan ve gösterilen tavsiyelere uymadıklarında başlarına gelecek olumsuz sonuçlara işaret edecek şekilde lanse edilmektedir. Korku çekiciliği mesajları yoğunluklu olarak duygusal ögelere hitap etmektedir. Öncelikli olarak bir tehdit yansıtılmış yansıtılan bu tehdit üzerinden de korku meydana getirilmeye çalışılmıştır. En sonda ise bu tehdit ile başa çıkacak dolayısıyla korkuyu ortadan kaldıracak öneriler sunulmuştur. İfadeler negatif söylemlerle doludur. İnsanların riskli durumlarla karşı karşıya olduğunu belirten maddi ve manevi hasara uğratacak tehdit sözcükleri içeren ifadeler oldukça fazla kullanılmıştır.

Örneklemlerde incelenen reklamlara bakılarak kullanılan korku çekiciliği unsurların içerdiği tehditlerin ağırlıklı olarak kişisel ve sosyal tehditler bazında olduğu tespit edilmiştir. Fnish'in suyun sonu görünüyor reklam filmi, Rexona'nın deodorant reklamları ve Veet'in istenmeyen tüyler reklamında sosyal tehdit unsurları ile karşılaşılmıştır. Bu anlayışa göre toplumda diğer insanlarla bir arada yaşayan bireylerin, diğer bireylerle girdiği ilişkilere ve etkileşimlere bağlı olarak yașadığı korkular ele alınmakta ve insanlar 
diğer insanlar tarafından beğenilmeyerek toplumdan dışlanma korkusu yaşamaktadırlar. Ayrıca tüm toplum ilgilendiren sosyal meseleler de işlenmektedir. Reklamlarında bu husustan yola çıkarak toplum tarafından beğenilmeme, dışlanma unsurları işlemesi ve toplumun susuz kalma tehlikesinin yansitılması nedeniyle bu reklamlarda sosyal tehdit unsurlarının işlendiği söylenebilir. Ziraat, Allianz, Axa sigorta reklamları, Domestos ve Calgon reklamlarında ise bireylerin başına gelebilecek olumsuz olayların yansıtılması, bu reklamlarda kişinin sahip olduğu ve ona memnuniyet veren bir özellik ya da durumun kaybı halinde olacak sonuçlar üzerinden korku yaratılması sebeplerinden ötürü kişisel tehdit unsurlarının kullanıldığı tespit edilmiştir. Ayrıca kişisel tehdit unsurları vurgulanırken kişinin bedenine aldığı hasar görüntülerine de yer veren sigorta reklamlarında kısmen fiziksel tehdit unsurlarının da kullanıldığı yorumlanabilmektedir.

İncelenen tüm reklamlarda öncelikle tüketiciye korku ve tehdit mesajları verildiği daha sonra ise çözüm önerileri getirildiği görülmüştür. Bulgular neticesinde sektörlerin ilgilendiği konular kapsamında insanların herhangi felaket yaşamaması, hayatlarını güvence altında, rahat ve mutlu șekilde yaşamalarının yolunun kendi ürünlerinin satın alınmasına bağlı olduğu mesajıdır. Ya da başlarına gelen istenmeyen bu durumlarda kurtuluş yolu olarak kendi ürünlerini sunmuşlardır. Reklamların tamamında çözüme yönelik sunulan ortak tema eğer o ürünler kullanmazsa insanların başına çeşitli felaketler geleceği, bu sorunlarla mücadele etmek durumunda kalmak istenmiyorsa o ürünler kullanımının şart olduğu anlayışıdır.

Korku çekiciliği reklamlarının ağırlıklı olarak sigorta ve kasko şirketlerince uygulandığı görülmüştür. İş yerlerinden taşıtlara, konutlardan kişilere bireysel olarak güvence sağlayan sigorta şirketleri yaşamımızda maruz kalabileceğimiz riskleri ön plana çıkararak korku oluşturduğu saptanmıştır. Ayrıca kişisel bakım ürünleri ve ev temizliği ürünleri hizmeti veren markalarında korku çekiciliği unsurlarını yoğun olarak kullandığı ortaya çıkarılmıştır. Bu markalar ise kendimize ve evdeki eşyalarla sağladığımız temizliğe dikkat etmediğimiz sürece toplumca dışlanabileceğimiz, tolum bazında sorunlarla karşılaşabileceğimiz, çeşitli temizlik araç ve gereçlerinin hasar görebileceği hususuna korku yoluyla dikkat çekmişlerdir. Dolayısıyla sınırlanan reklamlar boyutunda korku çekiciliği içeren reklamların daha çok sigorta şirketleri, kişisel bakım ürünleri ve diğer temizlik ürünleri markalarınca kullanıldığı söylenilebilir.

Elde edilen bulgular neticesinde 2018-2019 yıllarındaki korku çekiciliği reklamlarını kapsayan bu çalışma son yılarda da geçmiş yıllarda olduğu gibi benzer sektörler tarafından benzer mesajlar içerdiği görülmüştür. Araştırma insanlara ürünlerini kullandırmaya çalışan markların tüketici üzerinde nasıl korku oluşturarak onları ikna etmeye çalıştığını göstermesi bakımından önem arz etmektedir.

\section{Kaynakça}

Becan, C. (2019). Reklamcılıkta Distopya Gerçeği: Reklamlara Yönelik Bir Analiz. Akdeniz İletişim Dergisi (31), 147-170.

Brooker, G. (1981). A Comparison of the Persuasive Effects of Mild Humor and Mild Fear Appeals. Journal of Advertising , 10 (4), 29-40.

Classer, R. (1972). Planlı Pazarlama. İstanbul: İstanbul Reklam Yayınları.

Cüceloğlu, D. (2008). Korku Kültürü. İstanbul: Remzi Kitabevi. 
Çakı, C. (2018). Weımar Cumhuriyeti’nde Bolşevizm'in Korku Çekiciliği Bağlamında Alman Propaganda Posterlerinde Kullanımı. Karadeniz Teknik Üniversitesi İletişim Fakültesi Elektronik Dergisi , 5 (16).

Davies, M. (1993). Developing Combinatons of Message Appeals for Campaign Management. European Journal of Marketing , 27 (1), 51.

Debiec, J., \& Joseph, L. (2004). Fear and the Brain. Social Research , 71 (4), 807.

Elden, M., \& Bakır, U. (2010). Reklam Çekicilikleri Cinsellik, Mizah, Korku (1 b.). İstanbul: İletişim Yayınları.

Eren, A. “. (2005). Korku Kültürü, Değerler Kültürü ve Şiddet. Sosyal Politika Çalışmaları Dergisi , 8 (8).

Fisher, M. (2012). Introduction to Defining'Fear. A Spectrum Approach.

Furedi, F. (2017). Korku Kültürü. (B. Yıldırım, Çev.) İstanbul: Ayrıntı Yayınları.

Güler, A. (2001). Korku Kültürü Yerine Değerler Kültürü. Abant İzzet Baysal Üniversitesi Eğitim Fakültesi Dergisi .

Johnston, A. C., \& Warkentin, M. (2010). Fear Appeals and Information Security Behaviors: An Empirical Study. MIS Quarterly, 34 (3), 549-566.

Kalender, A. (2005). Siyasal İletişim Seçmenler ve İkna Stratejileri (2 b.). Konya: Çizgi Kitabevi.

Kekes, J. (2013). Fear and Reason. Philosophy , 88 (4).

Kocabaş, F., \& Elden, M. (2011). Reklamcılık Kavramlar, Kararlar, Kurumlar (12 b.). İstanbul: İletişim Yayınları.

La Tour, M., \& Zahra, S. (1988). Fear Appeals as Advertising Strategy: Should They be Used ? Journal of Services Marketing , 2 (4), 5-13.

Lennon, R., \& Rentfro, R. (2010). Social Marketıng And Distracted Driving Behaviors Among Young Adults: The Effectıveness Of Fear Appeals. Academy of Marketing Studies Journal , 14 (2), 95-113.

Leventhal, H. (1971). Fear appeals and persuasion: the differentiation of a motivational construct. Am J Public Health , 61 (6), 1208-1224.

Madran, A. D. (2019). Tutum, Tutum Değişimi ve İkna Temel Kavram, Kuram ve Araştırmalar (3 b.). Ankara: Nobel Yayınları.

Mannoni, P. (. (1992). Korku. (I. Gürbüz, Çev.) İstanbul: İletişim Yayınları.

Mazıcı, E., \& Çakı, C. (2018). Adolf Hitler'in Korku Çekiciliği Bağlamında Kamu Spotu Reklamlarında Kullanımı. Erciyes İletişim Dergisi , 5 (3), 290-306.

Mongeau, P. A. (1998). Bunu mu demek istediniz? Mongeau, P.A. (1998). Another look at fear-arousing persuaPersuasion: Advances Through Meta-analysis. I. M. W.Preiss içinde, Another Look at Fear-arousing Persuasive Appeals (s. 182-196). Cresskill: NJ Hampton Press.

O’Keefe, D. J. (1990). Persuasion: Theory and Research. California: Sage Publications.

Öztürk, U., \& Sevinç, H. (2017). Korku Pazarlama Çerçevesinde Suriye Hükümeti'nin Silah İthalatını Arttıran Etkenler. Uluslararası Sosyal Araştırmalar Dergisi , 10 (54). 
Ray, M. L., \& Wilkie, W. L. (1970). Fear: The potential of an appeal neglected by marketing. Journal of Marketing , 34 (1), 54-62.

Rogers, R. W. (1975). A Protection Motivation Theory of Fear Appeals and Attitude Change. Journal of Psychology, 91 (1), 93-114.

Roland, L., \& Russell, T. (1996). Kleppner's Advertising Procedure. New Jersey: PrenticeHall, Inc.

Ruiter, R. A., Kessels, L. T., Peters, G.-J., \& Kok, G. (2014). Sixty Years of Fear Appeal Research: Current State of the Evidence. International Journal of Psychology , 49 (2).

Salmanova, L., Ergin, Ç. T., \& Yılmaz. (2018). Reklamlarda Cinsel Çekicilik Kullanımının Tüketiciler Üzerinde Etkisi: Biscolata Reklamlarının Youtube Kanalı Üzerinden Netnografik Bir İncelemesi. International Journal of Social Sciences , 1 (2).

Sheer, V. C., \& Chen, L. (2008). Intrinsic Characteristics of Health-Related Fear Appeals from Chinese Print OTC Ads: Implications for Fear Message Construction. International Journal of Communication , 2, 936-958.

Siu, W. (2010). Fear Appeals and Public Service Advertising: Applications to Influenza in Hong Kong. Health Communication , 25 (6-7), 580.

Smith, E. R., \& Mackie, D. (2007). Social Psychology. USA: Psychology Press.

Strong, J. T., \& Dubas, K. M. (1993). The Optimal Level of Fear-Arousal in Advertising: An Empirical Study. Journal of Current Issues \& Research in Advertising , 15 (2), 93-99.

Tarakcı, H. N. (2019). İkna Edici Mesaj Stratejisi Olarak Cekicilik ve Kamu Spotlarında Kullanımı. Konya: Selçuk Üniversitesi Sosyal Bilimler Enstitüsü(Yayımlanmamış Doktara Tezi).

Tdk. (2020). tdk.gov.tr.

Terblanche, S. M., \& Terblanche, N. S. (2010). Race and Attitude Formation in HIV/AIDS Fear Advertising. Journal of Business Research , 63, 121-125.

Tour, M. L., \& Rotfeld, H. (1997). There are Threats and Fear Caused Arousal: Theory and Confusions of Appeals to Fear and Fear Arousal Itself. Journal of Advertising , 26 (3), 45- 59.

Williams, K. C. (2012). Fear Appeal Theory. International Journal of Economics and Business Research , 5, 63-82.

Witte, K. (1992). Putting the Fear Back İnto Fear Appeals: The Extended Parallel Process Model. Communication Monographs, , 329-349.

Witte, K., \& Allen, M. (2000). A Meta-Analysis of Fear Appeals Implications for Effective Public Health Campaigns. Health Education Behaviour: the official publication of the Society for Public Health Education , 27, 591-615. 


\title{
The Use of Fear Appeal in Advertisements: An Analysis of Television Advertisements
}

\author{
Mehmet Burç (Ph.D. Student) \\ Derya Başakcı (Res. Asst.) \\ Mustafa Koçer (Prof. Dr.)
}

\section{Extended Abstract}

Undoubtedly, television advertisements come first among the advertising activities carried out to convince consumers. Brands use various attractiveness elements in television advertisements to convince the target audience.

Advertisement attractiveness can also be called the motive that is driven by the advertisement (Roland \& Russell, 1996, s. 512). One of the most widely used techniques among the attractiveness elements in advertisements is fear attraction. With these advertisements, brands create fear and threats to people and almost force people to buy the product. Based on all these, the elements of fear attractiveness used in advertisements will be discussed.

Fear attractiveness is an advertising method that indicates that consumers should take measures against any situation or event recommended by using fear elements. In case they do not, it aims to attract attention to unfortunate events that may happen and persuade people through threats (Mazıcı \& Çakı, 2018, s. 292).

Witte divided the factors affecting fear attraction into three categories as fear, threat and competence (Witte, 1992, s. 330). The fear attraction models used in advertisements are the impulse model, the parallel response model, the Thayer drive model, the hedge motivation theory and finally, the expanded parallel processing model (Elden \& Bakır, 2010, s. 287).

Propulsion Model: It is a model in which fear is conceptualized as a force used to motivate individuals to save from an unpleasant situation (Williams, 2012, s. 68).

Parallel Response Model: In this model proposed by Leventhal in 1970, she expressed the parallel reaction processes in fear attractiveness as two separate processes, danger control processes and fear control processes, but also potentially interdependent processes (Witte \& Allen, 2000, s. 593).

Thayer Drive Model: While a positive emotion will mediate the stimulus to the advertisement, which has a moderate fear appeal element, messages that generate high tension will cause tension (Williams, 2012, s. 70).

Protection Motivation Model: According to this model, individuals react to messages containing elements of fear appeal by considering various factors (Elden \& Bakır, 2010, s. 294).

Extended Parallel Processing Model: According to this model, individuals first evaluate the fear element of the message and the more they believe that they are faced with a serious threat, the earlier they start the second evaluation (Witte \& Allen, 2000, s. 594). 
Advertisements try to provide the lifestyle and habits they want on individuals with the pressure they build on fear. It maintains this pressure in the economic field as well as in the political and social field. The underlying thought of advertisements that contain fearful appeal is to irritate individuals and instil discontent with them by making them feel inadequate. People are shown to achieve perfection to the extent that they consume the product through fear (Becan, 2019, s. 151-152).

The study aims to try to show how fear attractiveness, which is one of the most frequently used attractiveness methods used to provide consumer consent behavior, is used, in what ways it is processed and how it is conveyed to the target audience in advertisements carried out to raise awareness in an intensely competitive environment. The main importance of the research is to examine the fear elements in the advertisements and to analyze what kind of messages they give on purchasing behavior and to try to create awareness on this issue.

In the study, the advertisements containing the message of fear appeal on TV will be explained by using the semiotic analysis technique, which is a qualitative research method.

Since the advertisements including fear elements are investigated in our research, the advertisements containing fear appeal constitute the universe of our study. The purposeful sampling technique was used in the study. Television advertisements were taken as a sample.

The advertisements dealt with were limited to national television channels. The study is restricted to include the years 2018 and 2019. Due to the difficulty of accessing all advertisements in 2018 and 2019, the sample was limited to two advertisements suitable for each model that forms the basis of the fear appeal.

Research questions;

- How were the messages containing horror to convince the target audience in television advertisements denoted and which expressions were highlighted?

- What types of threats are predominantly used in advertisements?

- How are the solutions offered to eliminate the fear in the advertisements?

- Adhering to the examples examined, in which sectors are the advertisements containing fear appealing messages mostly seen?

Results and Findings; Messages containing fear appeal are presented in a way that points to negative consequences for people when they do not follow the advice described and shown in the advertisements. Fear appeal messages address emotional elements predominantly. First of all, a threat was reflected and fear was tried to be created through this threat. Statements are full of negative statements. Phrases containing threatening words that will cause material and moral damage to people who are faced with risky situations have been used a lot.

By looking at the advertisements examined in the samples, it was determined that the used threats containing the fear-attracting elements were mainly based on personal and social threats. The fears experienced by individuals living together with other people in the society, depending on the relationships and interactions they have with other individuals are discussed and people experience the fear of being excluded from the 
society by not being liked by other people. Moreover, social issues that concern the whole society are also covered.

The common theme suggested for the solution in all advertisements is the understanding that if those products are not used, various disasters will happen to people, and if they do not want to struggle with them, the use of those products is a must.

It has been observed that the fear attraction advertisements are mostly applied by insurance and motor own damage companies. Besides, it has been revealed that the brands that provide personal care and home cleaning products use the fear appeal elements intensively.

Keywords: Fear, Fear Appeals, Fear Appeals Models, Advertisement, Semiotics.

Bu makale intihal tespit yazııımlarıyla taranmıştır. Intihal tespit edilmemiştir.

This article has been scanned by plagiarism detection softwares. No plagiarism detected.

Bu çalışmada "Yükseköğretim Kurumları Bilimsel Araştırma ve Yayın Etiği Yönergesi” kapsamında uyulması belirtilen kurallara uyulmuştur.

In this study, the rules stated in the "Higher Education Institutions Scientific Research and Publication Ethics Directive" were followed.

Yazarların çalışmadaki katkı oranları; birinci yazar $\% 35$, ikinci yazar \%35, üçüncü yazar \%30.

Contribution rates of the authors in the study; first author $35 \%$, second author $35 \%$, third author $30 \%$.

Çalışma kapsamında herhangi bir kurum veya kişi ile çıkar çatışması bulunmamaktadır.

There is no conflict of interest with any institution or person within the scope of the study. 